(28)

\title{
2 足歩行系のサーボ・モデルによる解析
}

(名古屋大学) 伊藤宏司 - 藤井久一・伊藤正美

\section{1. まえがき}

人閂の歩行特性は, 従来, 生理学・運動学の立場か ら実馻的汇調べられてきた，最近では，2足歩行の動 的特性を数式モデルにより解析する研究も活発になっ てきだ ${ }^{(1)}$. しかし，一般的な 2 足歩行系の数式モデ ルは多変数・非線形の複雑な微分方程式になる。従っ て，運動の一部を時間関数であらかじめ与兄て制御則 を簡単化したり，脚の質量を無視したり，あるいは運 動を平面内に限定したりして，自由度を減らす工夫が 行われている。このようなモデルで種々の歩行条件を 解析することは，2 足歩行系の基本的特性を理解する らえで垂要であり，その結果惊，歩行機械の設計や人 間の歩行様式との定量的な比较等応用することがで きる。

さて， 2 足歩行系では姿勢と歩容の動的安定性が重 要な課題であり，このテーマを扱った諭文は多(6) -9).
ただ，従来の研究は脚を一定のアルゴリズムに従って 動かしたり6)，あるいは脚の切換時のみ淛御を加え るなど8フ,9，歩容の安定性という面では十分とはい觉 ない。

以上の観点から，本諭文では 1 用体・無質量脚の簡 単なモデルを用いて，動的に安定な 2 足歩行を実現す るためのフィードバック制御則について考察する。す なわ⿱ 行系が何らかの外乱を受けたとき，何ステップか後に 定常歩行（上体をある角度に保持し，周期的に脚を切 り換穴一定速度で前進する）に復㷌するための制御則 を導出する。これにより，例点ば，人間の歩行開始時 の動特性など過渡状態も解析できるようになる。

\section{2. 歩行モデルと運動方程式}

本論文では, 因1のよらな1つの剛体ボディとボデ イに比校して質量が無視できる 2 本の脚から成る 2 足

\section{記号の説明 (一部)}
$T:$ 脚の切換周期 (一定)
$u$ : 操作量 $\left(=(M, N)^{\prime}\right)$
$\bar{V}:$ 平均前進速度
$\boldsymbol{x}:$ 歩行系の状態変数 $\left(=(\varphi, \dot{\varphi}, \theta, \dot{\theta})^{\prime}\right)$
$x_{b}:$ ボディの状態变数 $\left(=(\varphi, \dot{\varphi})^{\prime}\right)$
$x_{L}:$ 脚の状態変数 $\left(=(\theta, \dot{\theta})^{\prime}\right)$
$z:$ 目標関数発生システムの状態变数

$\beta_{0}, \beta_{1}$ : 目標関数発生システムの特性パラメータ $\alpha_{0}, \alpha_{1}:$ ボディの特性パラメータ

$\theta, \varphi:$ 脚㧍よびボディが鉛直軸となす角 (矢印の方向を正とする)

$\theta_{\text {new }}$ : 切換後の脚の角度

$\theta_{\text {old }}:$ 切換前の脚の速度

$\theta_{\text {max }}:$ 脚の最大傾き角（定常歩容） 


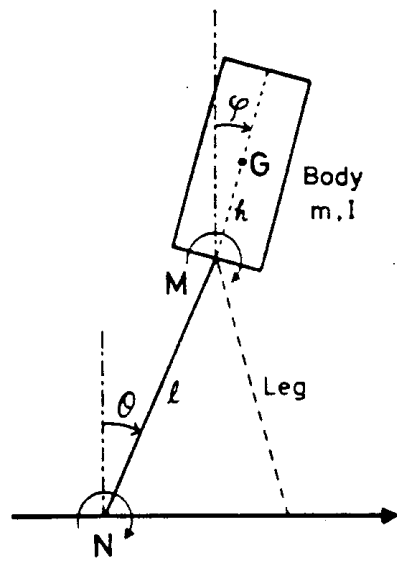

図 12 足歩行モデル (Sagittal Plane)

歩行系を考える，そして，次の仮定を設ける。

（1）人間の歩行でみられる両脚支持の期間はないも のとする、すなわち，ボディはつねにいずれか一方の 脚のみで支持され，脚の切換は瞬間的に行われるとす る.

(2) 脚の切換周期 $(T)$ および支持脚の長さ $(l)$ はつねに一定とする。

（3）歩行運動は進行方向と鉛直軸で定義される平面 (sagittal plane) に限定する.

（4）足部は小さく，支持脚は一点で接地する，また， 足と床の間には十分な摩擦力が㗢き，滑らないとする。

（5）運動は股関節と足首関節に作用するトルク $M$, Nで駆動される。

以上の仮定のもとで図 1 の歩行系の運動方程式を求 める。この系は 2 自由度であるから 2 組の非線形微分 方程式になる：

$m l h \cos (\theta-\varphi) \cdot \ddot{\varphi}+m l^{2} \ddot{\theta}+m l h \sin (\theta-\varphi) \cdot \dot{\varphi}^{2}$

$-m g l \sin \theta=N-M$

$\left(I+m h^{2}\right) \ddot{\varphi}+m l h \cos (\theta-\varphi) \cdot \ddot{\theta}$

$-m l h \sin (\theta-\varphi) \cdot \dot{\theta}^{2}-m g h \sin \varphi=M$ ここで， $\varphi, \dot{\varphi}, \theta, \dot{\theta}$ が小さいるして，(1)，(2)式を $(\varphi, \dot{\varphi}, \theta, \dot{\theta})=(0,0,0,0)$ の近傍で線形近似する と,

$$
\begin{aligned}
& m l h \ddot{\varphi}+m l^{2} \ddot{\theta}-m g l \theta=N-M \\
& \left(I+m h^{2}\right) \ddot{\varphi}+m l h \ddot{\theta}-m g h \varphi=M
\end{aligned}
$$

となる。この線形微分方程式を状態 $x=(\varphi, \dot{\varphi}, \theta, \dot{\theta})^{\prime}$, 操作量 $u=(M, N)^{\prime}$ (' 状態方程式に書き直すと次式を得る。

$$
\dot{x}=A x+B u
$$

$$
A=\left(\begin{array}{cc:cc}
0 & 1 & 0 & 0 \\
a_{1} & 0 & a_{2} & 0 \\
\hdashline 0 & 0 & 0 & 1 \\
a_{3} & 0 & a_{4} & 0
\end{array}\right), \quad B=\left(\begin{array}{cc}
0 & 0 \\
b_{1} & b_{2} \\
\hdashline 0 & 0 \\
b_{3} & b_{4}
\end{array}\right)
$$

ここで, $a_{1}=m g h / I, \quad a_{2}=-m g h / I, \quad a_{3}=-m g h^{2} / l I$, $a_{4}=\frac{g}{l}\left(1+m h^{2} / I\right), \quad b_{1}=\left(1+\frac{h}{l}\right) / I, \quad b_{2}=-h / l l, b_{3}=$ $-\{1+m h(l+h) / I\} / m l^{2}, \quad b_{4}=\left(1+m h^{2} / I\right) / m l^{2}$ であ る.

以下，この状態方程式に基づいて，(i)ボディの姿勢 の安定および(ii)歩容の安定を達成するために，必要な フィードバック制御則を考察する。

\section{3. 歩容パラメータと目標関数}

制御則を求める前に，目標となる脚の動き（定常步 容）を平均前進速度 $(\bar{V})$ ，歩幅 $(S)$ ，脚の切換周期 （T）などの歩容パラメータで規定し，時間関数で表 わしておく，例灾ば，脚の触を図 $2($ a)のように，直 線的に変化させたい場合には，目標関数を

$$
\begin{aligned}
& r(t)=-\theta_{\max }+\bar{V} \cdot(t-n T) \\
& n T \leqq t \leqq(n+1) T \quad n=0,1,2, \cdots \quad(6)
\end{aligned}
$$

とする。ここで， $\theta_{\max }$ は脚の最大傾き角で $\theta_{\max }=$ $\sin ^{-1}(S / 2 l)$ である.これは，いつも一定の速度で脚 を動かす步行様式である。また，図2(b)のように脚を 動かす場合には，目標関数を

$$
r(t)=c_{1} e^{a t}+c_{2} e^{-a t} \quad 0 \leq t \leq T
$$

とする. 係数 $C_{1}, C_{2}, a$ 忡，

$$
r(0)=-\theta_{\max }, \quad r(T)=\theta_{\max }, \quad \dot{r}(0)=\dot{r}(T)=\omega_{0}
$$

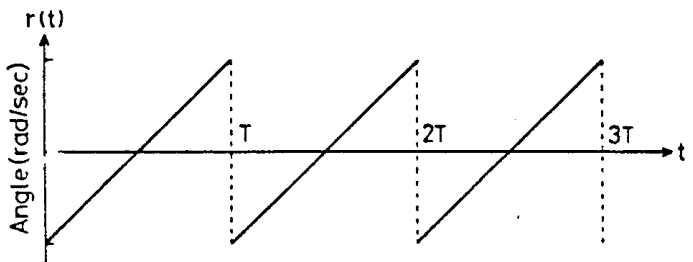

(a)

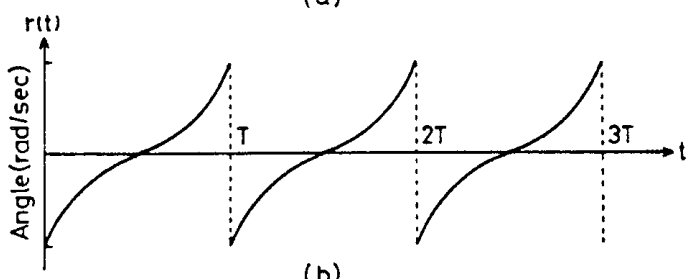

(b)

図 2 定常歩容における脚の運動を表わす 目標関数（振幅 $=2 \theta_{\max }$ ） 
より決める。ここで， $\omega_{0}$ は脚が切り換わるときの角 速度である。

これ以外にも種々の定常歩容 (目標関数) が考兄ら れるが，それらを一括して次式の状態方程式の出力で 表わす10).

$$
\begin{aligned}
&\left\{\begin{array}{l}
\dot{z}=G z \\
r=h^{\prime} z
\end{array}\right. \\
& \text { ここで, } \quad z=\left(z_{1}, z_{2}\right), \quad G=\left[\begin{array}{cc}
0 & -\beta_{0} \\
1 & -\beta_{1}
\end{array}\right],
\end{aligned}
$$

$h=[0,1]^{\prime} ，\left(G, h^{\prime}\right)$ : 可観測である. 脚の切換を考 慮して，この系は $T$ 秒每に初期值にリ七ットする。以 後，(8)式を目標関数発生システムと呼ぶ.(8)式を微分 方程式の形に書き直すと

$$
\ddot{r}+\beta_{1} \dot{r}+\beta_{0} r=0
$$

となる. 従って, 出力 $r(t)$ は 2 次の微分力程式の解 として得られる関数をすべて含んでいる。 それ故，こ の系はパラメータ, 初期值を適当に選べば, かなり多 くの関数（例・正弦波，2次曲線など）を発生させる ことができ，種々の定常歩容を表現できる，例えば， (6)式の関数の場合には, $\beta_{0}=\beta_{1}=0$ とし, 初期値を $z_{1}(0)=\bar{V}, \quad z_{2}(0)=-\theta_{\max }$ とすればよい.

\section{4. 動的安定のための制御則}

前章のように，定常歩容を時間関数で与えれば，歩 容の安定性はこの時間関数に対して脚の運動を追従さ せることで実現できる，従って，姿勢および歩容の安 定問題は制御の観点から見直すと，次のように言いか えることができる.

『任意の初期状態 $x(0)$ からボディの变数 $(\varphi)$ を 一定值に漸近的に近つけ，かつ，脚の变数 $(\theta)$ を歩 容ハラメータで規定される目標関数 $r(t)$ に追従させ るには，操作量であるトルク $(M, N)$ を状態変数 $\boldsymbol{x}$ $=(\varphi, \dot{\varphi}, \theta, \dot{\theta})^{\prime}$ の関数としてどのように決めればよ いか? 』

さて（5)式の行列 $A ， B$ 形からわかるように，ボ ディの変数 $(\varphi, \dot{\varphi})$ と脚の変数 $(\theta, \dot{\theta})$ とは相互に干 涉し合っている．また，特性方程式 $A-\lambda I=0$ より特 性根（固有值，極上むいう）を求めてみると，

$$
\lambda^{2}=\frac{1}{2}\left(a_{1}+a_{4} \pm \sqrt{\left(a_{1}-a_{4}\right)^{2}+4 a_{2} a_{3}}\right)
$$

となり， $a_{1}>0 ， a_{4}>0$ より不安定根を含むことがわか る.

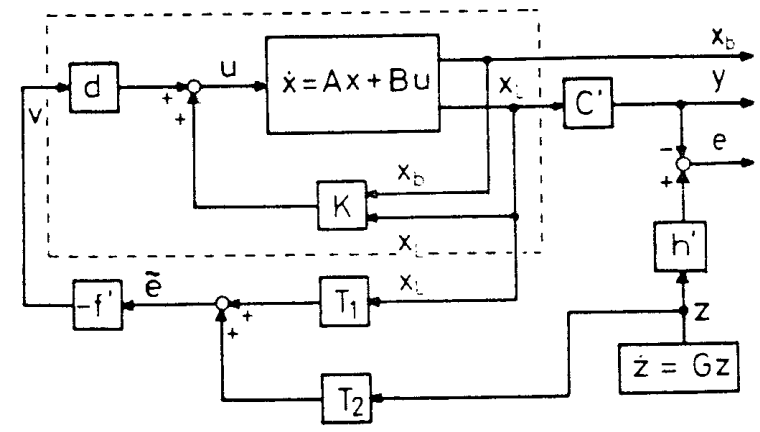

図3状態フィードバック制御則

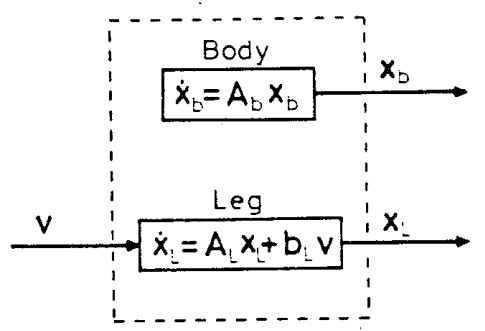

図 4 非干涉化後のボディおよび脚の状態方程式

以上を考虑して，制御則として図 3 のよらな 2 重ル ープの状態フィードバックを構成する.

[1] まず，ボディと脚の運動の相互干渉を打ち消 し，同時にボディが安定になるように極を左半平面に 移!，脚については目標関数発生システムと同じ極を もつようにする。これらは，いずれも極指定の問題で あり，(5)式の系が可制御であれば，状態 $\boldsymbol{x}$ のフィー ドバックにより，つねに可能であることが知られてい る11). 具体的には次のような手順で行う.

状態フィードハシック

$$
\begin{aligned}
& u=K x+d v \quad \text { ただし } K=\left[\begin{array}{llll}
k_{11} & k_{12} & k_{13} & k_{14} \\
k_{21} & k_{22} & k_{23} & k_{24}
\end{array}\right], \\
& \boldsymbol{d}=\left[\begin{array}{l}
d_{1} \\
d_{2}
\end{array}\right] \text { である. }
\end{aligned}
$$

を行って，(5)式を(11)式に変換する.

$$
\dot{x}=(A+B K) x+B \cdot d \cdot v
$$

$$
\text { そして, } A+B K=\left(\begin{array}{cc:cc}
0 & 1 & 0 & 0 \\
-\alpha_{0} & -\alpha_{1} & 0 & 0 \\
\hdashline 0 & 0 & 0 & 1 \\
0 & 0 & -\beta_{0} & -\beta_{1}
\end{array}\right), B d=\left(\begin{array}{c}
0 \\
0 \\
\hdashline 0 \\
1
\end{array}\right) \text { (12) }
$$

となるように $K, \boldsymbol{d}$ を決める。これは $k_{i f}, d_{i}$ を末 知数として，代数方程式を解けば得られる。ここで， $\alpha_{0} ， \alpha_{1} ， \beta_{0} ， \beta_{1}$ はそれぞれの極を指定するためのパラ 
メータである。 $\alpha_{0}, \alpha_{1}$ はボディが漸近安定になるよ うに選び， $\beta_{0}, \beta_{1}$ は目標関数発生システムと同じ樰に なるように選ぶ。

この結果，図 3 の破線の内部㫕かけ上図4のよう になり，2つの独立なサブ・ジテムに分割される。

(i)ボディ: $\dot{x}_{0}=A_{b} x_{b}$

(ii)玼: $\dot{x}_{L}=A_{L} x_{L}+b_{L} \cdot v$

$$
\begin{aligned}
& \text { たただし， } x_{b}=[\varphi, \dot{\varphi}], \quad A_{b}=\left[\begin{array}{cc}
0 & 1 \\
-\alpha_{0} & -\alpha_{1}
\end{array}\right] \\
& x_{L}=\left[\begin{array}{ll}
\theta, & \dot{\theta}
\end{array}\right]^{\prime} \quad A_{L}=\left[\begin{array}{cc}
0 & 1 \\
-\beta_{0} & -\beta_{1}
\end{array}\right] \\
& b_{L}=\left[\begin{array}{l}
0 \\
1
\end{array}\right] \text { である. }
\end{aligned}
$$

[2]以上により，ボディの姿勢は安定に保持でき るので，次に脚の動きを目標関数発生システムの出力 $r(t)$ に追往させるよらに，状態フィードバックを行 万. 目標関数発生システムは脚の定常運動学表現して いるので，このよらに系を構成しておけば，外乱を受 けても，脚の動きはいつも定常歩容にもどることがで きる．脚に関する状態方程式だけをとり出し，出力に 関する部分をつけ加える。

$$
\begin{aligned}
& \left\{\begin{array}{l}
\dot{x}_{L}=A_{L} x_{L}+b_{L} \cdot v \\
y=c^{\prime} x_{L}
\end{array}\right. \\
& \text { ここで, } c^{\prime}=[1,0], \text { 従って } y=\theta(t) \text { である. }
\end{aligned}
$$

この系は, $\quad \operatorname{rank}\left[b_{L}, b_{L} A_{L}\right]=2, \quad \operatorname{rank}\left[c, A^{\prime} c\right]=2$ より可制御・可観测である。

(15)式の出力 $y(t)$ と目標関数発生システムの出力 $r(t)$ の差, $e=r(t)-y(t)$ が $t \rightarrow \infty$ で 0 になるよう に操作量 $v$ を決定できるかという問題である。これは， (i) 目標関数発生システムが可钼测，(ii) (15)式が可制御 - 可観測, かつ (iii) $A_{L}$ の固有蒀が, 目標関数発生シ ステムの $G$ の固有值をすべて含むならば可能であり， その設計法も確立されている12),13)。(iii)の条件は，[1] の状態フィードパックで $A_{L}$ の固有值を $G$ のそれに 一致させてあるので当然満たされている。また（i), (ii)の条件もそれぞれ成立しているので，操作量 $v$ を $x_{L}, z$ 状態フィードハシックで決定できる，付録に示 す設計法より，そのフィードハッック則は，

$$
\begin{aligned}
& v=-f^{\prime} \cdot \tilde{e} \\
& f^{\prime}=\left[\begin{array}{ll}
f_{1}, & f_{2}
\end{array}\right], \quad \bar{e}=T_{1} x_{L}+T_{2} z
\end{aligned}
$$

である(図 3 参照)．(16)式を(15)式に代入すると

$$
\dot{x}_{L}=\left(A_{L}-b_{L} f^{\prime} T_{1}\right) x_{L}-b_{L} f^{\prime} T_{2} z
$$

となる．脚は $T$ 秒毎に切り換える必要があるので，状 態 $x_{L}=(\theta, \dot{\theta})^{\prime}$ は一定の方式でリセットしなければ ならない：また，切換の前後で $|\tilde{e}|$ が增加すると， $\lim _{t \rightarrow \infty}\{r(t)-y(t)\}=0$ という漸近安定が保障されなく なる。ここ礼ら若慮して, 本稿では次式により切り換 えた。

(i) $\theta_{\text {new }}=\theta_{\text {old }}+2 r(0)$ if $\quad \theta_{\text {old }} \geqq 0$

(ii) $\theta_{\text {new }}=-\theta_{\text {old }}$ if $\theta_{\text {old }}<0$

(18) $\theta_{\text {old }}$ : 切換前， $\theta_{\text {new }}$ : 切換後

$\dot{\theta}$ は慣性系であるので不变之し芯。目標関数発生シ ステムも同時に， $r(T) \rightarrow r(0)$ にリセットされるので， 本稿の切換方式によ礼ば $|\bar{e}|$ は変化しない。

\section{5. シミュレーション}

以下の条件で計算機シミニレーションを行った。

シミュレーション [I]：脚を一定の角速度で動かす 歩容。従って, 前進速度はほぼ定になる $(V=l \cdot \dot{\theta}$ 。 $\cos \theta \cong l \cdot \dot{\theta}$ ).

(1) 歩行系： $m=50 \mathrm{~kg}, I=3 \mathrm{~kg} \cdot \mathrm{m}^{2}, h=0.35 \mathrm{~m}, l$ $=1.0 \mathrm{~m}$

（2）定常歩容のパラメータ：脚の切換周期 $T=0.5$ 秒 $/$ step, 脚の最大振れ角 $\theta_{\max }=0.25 \mathrm{rad}\left(\cong 14^{\circ}\right)$, 平均前進速度 $\bar{V}=1.0 \mathrm{~m} /$ 秒 $\left(\bar{V}=2 l \sin \theta_{\max } / T \cong\right.$ $2 l \theta_{\max } / T$ で近似している), ボディは直立に保持 する.

(3) 脚が追従すべき目標関数： $r(t)=-\theta_{\max }+\bar{V} \cdot t$, $\dot{r}(t)=\bar{V}$, 従って, 目標関数発生システムのパラ メータは $\beta_{0}=\beta_{1}=0$, その初期值 $z_{1}(0)=1.0$, $z_{2}(0)=-0.25$ である(図 2 (a)参照).

（4）特性パラメータ：六ディ $\rightarrow \alpha_{0}=15, \alpha_{1}=8$, こ のとき極は $(-5,0),(-3,0)$ になる. 脚 $\rightarrow f_{1}$ $=8, f_{2}=6$, 従って, 偏美システムの極は $(-4$, $0),(-2,0)$ になる。 $\alpha_{0}, \alpha_{1}, f_{0}, f_{1}$ の値の選 択により定常歩行に近づくはやさが決をる。

（5）初期值：ボディ $\rightarrow \varphi(0)=1.05 \mathrm{rad}, \dot{\varphi}(0)=0$, 脚 $\rightarrow \theta(0)=0, \dot{\theta}(0)=0$, ボディたけを前方へ大きく 約 $60^{\circ}$ 傾けた状態で歩行を開始する場合である。

シミュレーションで惊, 線形近似後の方程式(3)，(4) 式および非線形の運動方程式(1)，(2)式のそれぞれに対 して，第 4 章で得た状態つィードバック制御則を適用 してみた。非線形の方程式に適用した場合は安定性に 不安があったが，種々の初期液でシミュレーションし 


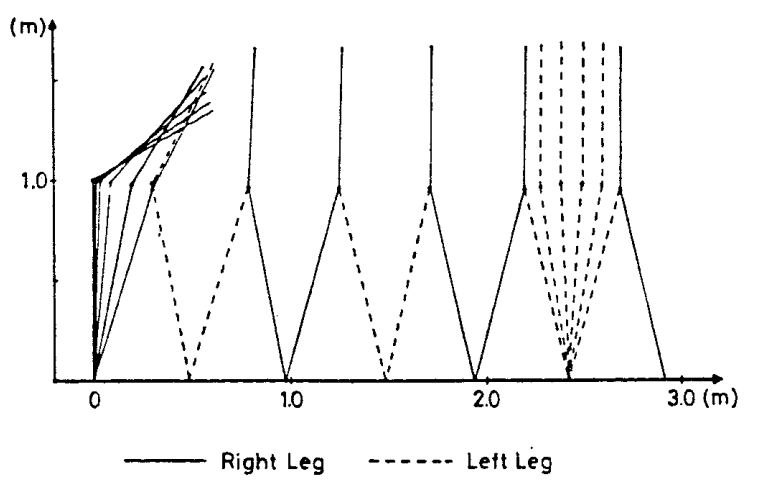

図 5 シミュレーション [I]: Stick Picture (非線形) $m=50 \mathrm{~kg}, \quad I=3 \mathrm{~kg} \cdot \mathrm{m}^{2}, l=1.0 \mathrm{~m}, h=0.35 \mathrm{~m}, T=$ 0.5 秒 $/ \mathrm{step}, \nabla=1.0 \mathrm{~m} /$ 秒， $\varphi(0)=1.05 \mathrm{rad}\left(\cong 60^{\circ}\right)$ $\dot{\varphi}(0)=\theta(0)=\dot{\theta}(0)=0.0$

た結果，いずれも安定に収束しており，有効であるこ とが確かめられた。

さて，図 5 は非線形の運動方程式に対して状態フィ 一ドバック制御則を適用した結果であり，ボディおよ び脚の動きを 0.5 秒每の切換時について示したもので ある.たたし，最初と最後のステップは 0.1 秒每に示 してある. 約 $60^{\circ}$ 前方に傾いた状態からボディを引き 起こし，同時に脚芯傾けて歩き始め，数歩で注注定常 歩容になっている。過渡状態では，脚の切換時の角度 が非対称になるため，股関節の位置が多少上下する。

これを解消するためには，脚長を可変にして，その制 御を付け加えなければならない。

次に角度の变化を詳しくみてみる。四 6 は $\theta, \varphi$, 図 7 は $\dot{\theta}, \dot{\varphi}$ の時間変化を示したものである。いずれ も，線形および非線形の両方のシミュレーション結果 が示してある. 脚の角度 $(\theta)$, ボディの傾き $(\varphi)$ と も3〜4 ステップで目標値に達している. 定常歩容で の $\dot{\theta}$ は線形では，ほほ满足いく結果に落ち着いてい るが，非線形では振動成分が残り，切換の前後で速度 が下がっている。また，ボディの角速度 $(\dot{\varphi})$ も非線 形の場合，脚の切換の影響を受けてかなり振動してい る.これは，線形では状態フィードハッックで干啮が打 ち消されるけれども，非線形方程式に適用した場合は， 相互干渉が残るためである。しかし，ボディの角度 $\varphi$ は非線形の方が早く0に近づく。

図8は駆動トルク $M, N$ を示している。線形・非 線形々も大体同じ傾向を示している，歩行開始時のト ルクの発生に特徵があり，足首のトルク $N$ は負の大 きな值から一度 0 に近づき，脚の切換時には再び大き な負の值をとっている。これに対し，股関節トルク $M$

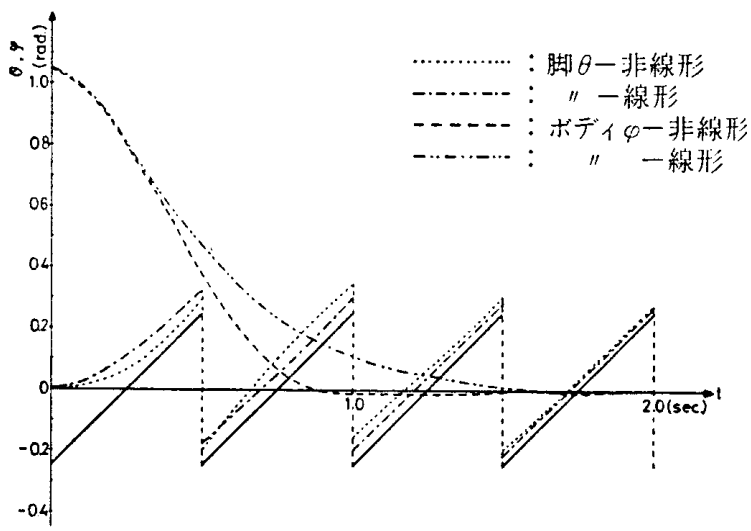

图6 シミュレーション［I］：ボディ㞧よび脚 の角度 (線形および非線形)

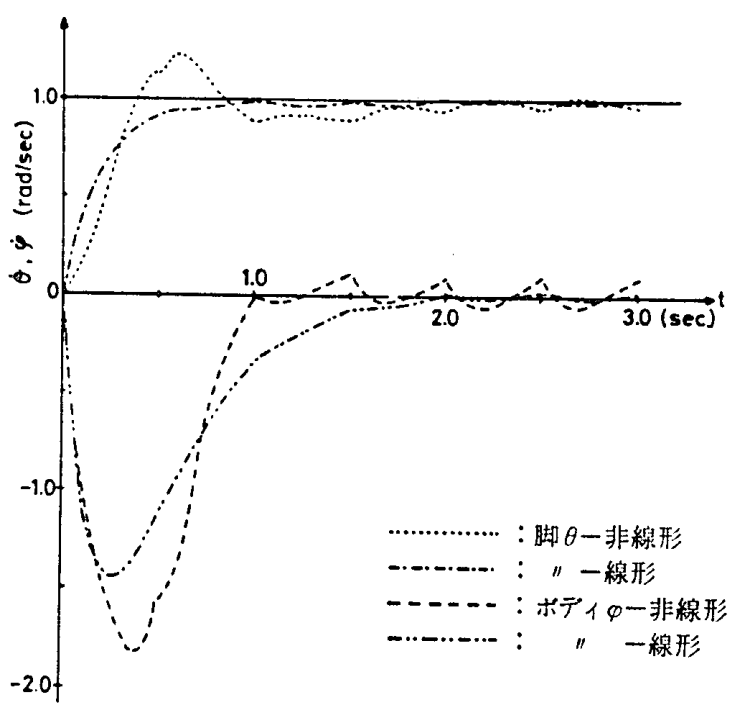

図 7 シミュレーション［I］：ボディおよび脚 の角速度（線形および非線形）

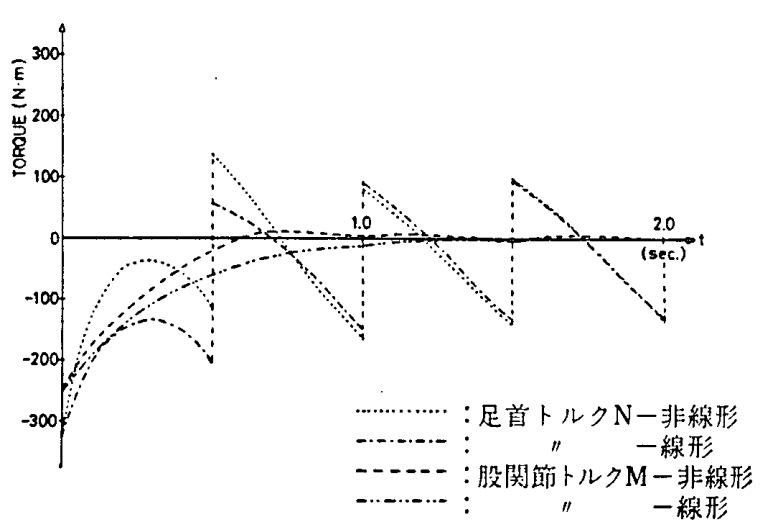

图 8 シミュレーション [I]：トルク $M, N$ （線形および非線形）

は漸近的に小さくなっている，歩き始めの $M, N$ の 大きなトルクはボディを引き起こすのに使われ，切換 に近いステップ後半の $N$ の大きなトルクは，脚が 前 


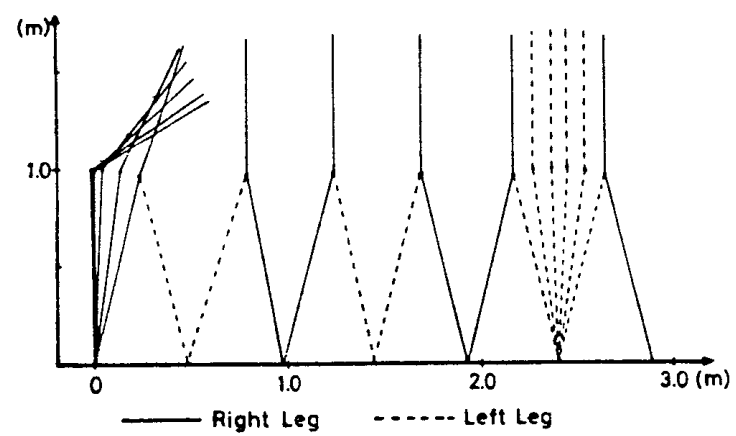

图 9 シミュレーション [II]: Stick Picture (非線形)

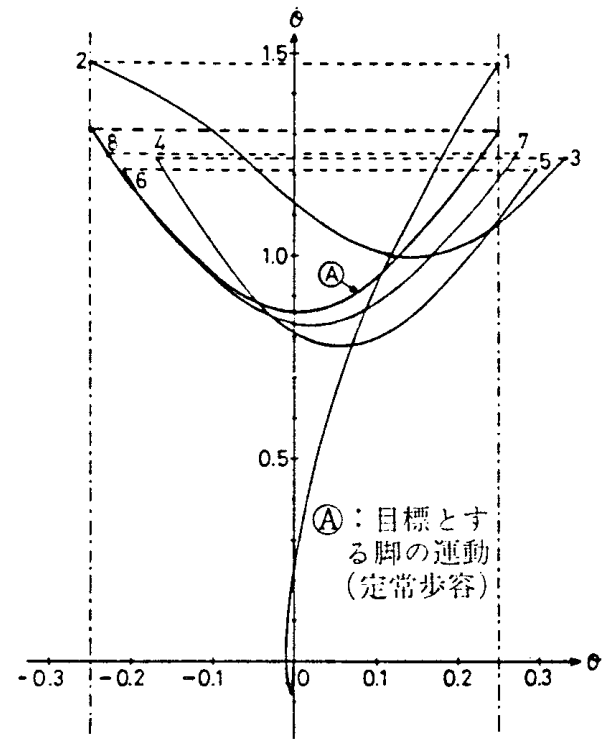

図 10 シミュレーション [П]: $\theta-\dot{\theta}$ 位相面軌 跡 (非線形)

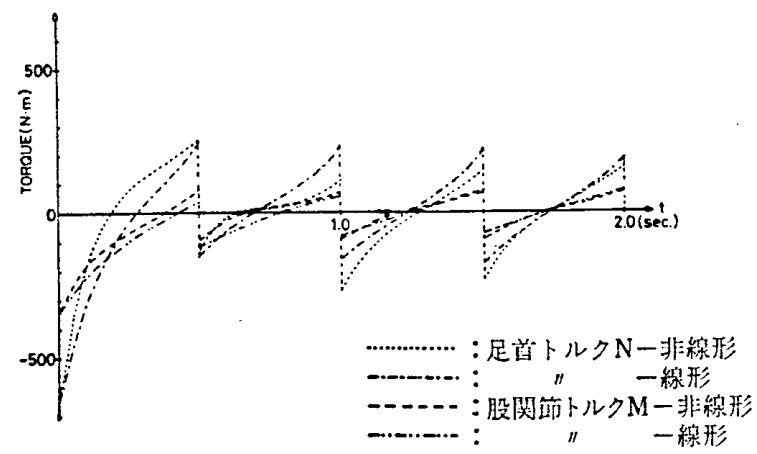

図 11 シミュレーション [I]：トルク $M, N$ （線形および非線形）

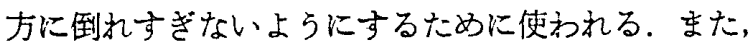
定常歩容になってからのトルク $N$ は1ステップの前 半が正の値，後半が負の值になっている。これは人間 の步行でい亲は，両脚支持期での “けり”之“衙突” に対応している。またこの歩容ではボディが直立状
態になると，股関節のトルク $M$ が非常に小さくなる

シミュレーション [II]：切換時にはやく，頂点でお そく脚を動かす歩容（脚に倒立振子と同じ特性を持た せる).

(3) 脚が追従すべき目標関数： $r(t)=0.039 e^{4 t}-$ $0.289 e^{-4 t}$. 目標関数発生システムのバラメータ结 $\beta_{0}$ $=-16, \beta_{1}=0$, 初期值は $z_{1}(0)=1.31, z_{2}(0)=$ -0.25 である [図 2 (b)参照].

(1)，(2)，(4)，(5)の条件はすべて［I］と同じである. 図 9 は，やはり，非線形の運動方程式について解い だ゙ディおよび脚の動きである．歩き始めにボディを 引き起こすとき，脚を若干後に傾けて反動を利用して いる (図10参照)．定常歩容に入ると， Stick Picture の間隔からわかるように，切換の前後で速度がはやく， 顶点でおそくなっている。

图10は， $\theta$ を横軸，白を程軸にとり，位相面軌跡を 描いたものである(非線形方程式に適用したデータ). 歩き始めに一度逆に応答して（脚を後に傾けて），そ れから急激に $\dot{\theta}$ を大きくして(1)達する。ここで脚 を切り換え(2になる。この時点で，角度は目標值と一 致しているが，白がまだかなり大きい，次の 1 歩の間 に角速度を沶として，(3)で脚を切り換える。(4)から始 まる3 歩目からは，倒立振子の特性と似た動きを示し， (5)〜7)を経て，5歩目でほぼ完全に目標関数と一致す る。図には示さなかったが，線形系に適用した場合は， 歩き始めの近応答はなく，また，2 歩目からほぼ定常 歩容になる.

次に，駆動トルク $M, N$ をみてみる（図11），線 形・非線形とも同じ傾向を示している．しかし，足首 トルク $N$ について図8 と比校すると，1ステップの 間で正負が全く逝になっている。この歩き方は，脚の 角速度をステップの中間で幄く，両端ではやくしなけ ればならないため，郝が切り換わるとすぐ負のトルク をかけて速度を和とし，ステップ後半では正のトルク で速度をあげている，ところで，足首に負のトルクを かけて脚を減速させると，当然ボデイは前に倒れよう とする，従って，ボディの直立を維持するためには， 股関節にも負のトルクをかける必要がある。正のトル クが足首にかかる場合も同様である。この理由から定 常歩容では，トルク $M, N$ が同じパターンになって いる。一方,シミュレーション[I]（因8）では, 定 常歩容になると脚を一定速度で動かすので，たとえ足 首にトルクがかかっても，ボディにはほとんど影響を 
及ぼさない，従って，股関節のトルク $M$ は非常に小 さい，このように，歩行様式によって，関節トルクの 発生パターンは大きく巽なる。

\section{6. むす び}

1 用体・無質量脚の簡単な2 足歩行系について, 姿 勢および歩容の動的安定性を制御の立場から考察した。 そして，歩容の動的安定をサーボ系の追従問題におき か光，外乱を受けても，つねに定常歩容に復帰できる ように制御系を構成した，本稿の制御モデルは定常歩 容を目標関数で規定しているので，いろいろな脚の動 きに追従できる利点がある，例えば，階段歩行時には それに適合するように目標関数を設定してやればよい。 また，歩行機械を設計する場台には，前方の道路状況 に忘して目標関数を設定し，それに追従させることが 必要になってくる。このときには，将来の目標関数も 現在の制御に利用できるので，筆者らが先に検討した 予見追值制御 (preview control) の考方方が有効と なるであるら ${ }^{(4)}$. 計算機シミュレーションでは線形近 似で得た状態フィードベック制御則を，非線形運動方 程式にも適用した。その結果，大きな初期外乱に対し ても，十分安定な歩行に復㷌できることがわかった。 本稿では，歩幅，切換周期を一定にして解析したが， これらを可変にして，ボディ，脚の状態にもとづいて 制御すれば，上り安定な歩行采が得られると思われる。 また，人間の步容と比較するためには，両脚支持期， 3 次元の動き，あるいは脚の質量や足の大きさの影響 も考慮して，歩行モデルをさらに精密にする必要があ る.

\section{参考文献}

1) M. Vukobratović：步行ロボットと人工の足，日刊 工業新開社 (1975).

2）山下・酒谷：線形モデルによる 2 足步行の特性解析， バイオメカニズム 3，(1975), pp. 252-260, 東京大学出 版会.

3）山㱦信寿: 2 足歩行の総合解析モデルとシミュレーシ ョン，バイオメカニズム 3，(1975)，pp. 261-269.

4) C. K. Chow and D. H. Jacobson: Studies of Human Locomotion via Optimal Programming. Mathematical Biosciences, 10, (1971), pp. 239-306.

5) M.A. Townsend and A. Seireg: The Synthesis of Bipedal Locomotion. J. of Biomechanics, 5, (1972), pp. 71-83.
6) M. Vukobratović, A. A. Frank and Juricić: On the Stability of Biped Locomotion. IEEE Trans. BME-17, (1970), pp. 25-36.

7) H.Hemami and P.C.Camana: Nonlinear Feed. back in Simple Locomotion Systems. IEEE Trans., AC-21, 6, (1976), pp. 855-860.

8) F. Gubina, H. Hemami, and R. B. McGhee: On the Dynamic Stability of Biped Locomotion. IEEE Trans. BME-21, (1974), pp. 102-108.

9）今泉・森：歩容に着目した理想化 2 足歩行モデルの統 一的唡討，バイオメカ二ズム 3，(1975)，pp. 243-251.

10) S. P. Bhattacharyya and J.B. Pearson: On the Linear Servomechanism Problem. Int. J. Control, 12, 5, (1970), pp. 795-806.

11) W.M. Wonham: On Pole Asssignment in Multi. input Controllable Linear Systems. IEEE Trans., AC-12, 6, (1967), pp. 660-665.

12）細江・伊藤(正): 線形サーボ問題に㧍忛るエラー・シ ステムについて，電気学会論文誌，92-C，10，(1972）, pp. 369-375.

13）伊藤(正)：システム制御理論，第8 章，昭晃堂(1973).

14）伊滕(正) - 伊藤(宏)：予测・予覚・予見制御系につ小 $\tau$, 電気学会論文誌, 95-C , 2,. (1975), pp. 30-36.

\section{付 録(状態フィードバックvの棈成法)}

(8)式拈よび(14)式の状態変数 $\boldsymbol{z} ， \boldsymbol{x}_{L}$ を用いて，偏差 ベクトル

$$
\tilde{e}=T_{1} x_{L}+T_{2} z
$$

を構成する。ここで， $T_{1}, T_{2}$ は

$$
U_{1}=\left[\begin{array}{c}
c^{\prime} \\
c^{\prime} A_{L}
\end{array}\right]=\left[\begin{array}{ll}
1 & 0 \\
0 & 1
\end{array}\right], \quad U_{2}=\left[\begin{array}{c}
h^{\prime} \\
h^{\prime} G
\end{array}\right]=\left[\begin{array}{cc}
0 & 1 \\
1 & -B_{1}
\end{array}\right]
$$

を使って，

$$
T_{1}^{-1} T_{2}=-U_{1}^{-1} U_{2}=\left[\begin{array}{cc}
0 & -1 \\
-1 & \beta_{1}
\end{array}\right]
$$

より求める。このとき

$$
T_{1}=\left[\begin{array}{ll}
1 & 0 \\
0 & 1
\end{array}\right], \quad T_{2}=\left[\begin{array}{cc}
0 & -1 \\
-1 & \beta_{2}
\end{array}\right]
$$

と選べる。して，この偏差 $\tilde{e}$ に関する状態方程式を

$$
\left\{\begin{array}{l}
\dot{\bar{e}}=\tilde{A} \tilde{e}+\tilde{b} \cdot v \\
e=\tilde{c}^{\prime} \cdot \tilde{e}
\end{array}\right.
$$

とする.ここで, $\tilde{A}, \tilde{b}, \tilde{c}^{\prime}$ は

$$
\tilde{A}=T_{1} A_{L} T_{1}^{-1}, \quad \tilde{b}=T_{1} b_{L}, \quad \tilde{c}^{\prime}=-c^{\prime} T_{1}^{-1}
$$

より決定する。この場合は， 


$$
\tilde{A}=\left[\begin{array}{cc}
0 & 1 \\
-\beta_{0} & -\beta_{1}
\end{array}\right], \quad \tilde{b}=\left[\begin{array}{l}
0 \\
1
\end{array}\right], \quad \tilde{c}=\left[\begin{array}{c}
-1 \\
0
\end{array}\right]
$$

（付 7)

となる. 状態フィードベック $v=-f^{\prime} \tilde{e}$ より

$$
\dot{\tilde{e}}=\left(\bar{A}-\tilde{b} f^{\prime}\right) \tilde{e}
$$

を得る。ここで，

$$
\widetilde{A}-\tilde{b} f=\left[\begin{array}{cc}
0 & -1 \\
-\left(\beta_{0}+f_{0}\right), & -\left(\hat{\beta}_{1}+f_{1}\right)
\end{array}\right]
$$

$$
\begin{aligned}
\tilde{e} & =\left[\begin{array}{ll}
1 & 0 \\
0 & 1
\end{array}\right]\left[\begin{array}{l}
\theta \\
\dot{\theta}
\end{array}\right]+\left[\begin{array}{cc}
0 & -1 \\
-1 & \beta_{1}
\end{array}\right]\left[\begin{array}{l}
z_{1} \\
z_{2}
\end{array}\right] \\
& =\left[\begin{array}{l}
\theta-z_{2} \\
\dot{\theta}-z_{1}+\hat{\beta}_{1} z_{2}
\end{array}\right]
\end{aligned}
$$

(付 5 ) 式上り

$$
e=[-1,0] \tilde{e}=z_{2}-\theta
$$

(8)式より, 出力 $r(t)$ で表わせば

$$
e=r-\theta
$$

となる. 従って, $\tilde{e}$ が渐近的に0に近つけば, $e=r-$ $\theta$ も 0 に近づき, 脚の角度 $\theta(t)$ は目標関数 $r(t)$ に 追従できる。 $f_{0} ， f_{1}$ を選べば，偏差べトル $\tilde{e}$ は漸近的に 0 に 近づく. そして, $x_{L}=(\theta, \dot{\theta})^{\prime}, z=\left(z_{1}, z_{2}\right)^{\prime}$, (付 1) 式拉よ゙（付 4 ) 式より 